\title{
PENINGKATAN KETANGGUHAN MASYARAKAT TERHADAP BENCANA TSUNAMI DENGAN MENGGUNAKAN METODE SIMULASI
}

\author{
Zulfikar Muhammad \\ Sekolah Tinggi Ilmu Kesehatan Kepanjen \\ Email: zoemoeh17@gmail.com
}

\begin{abstract}
Indonesia is a country with high-risk potential for various types of disasters because Indonesia is located between three large tectonic plates of the earth, namely the Eurasian Plate, the Indo-Australian Plate and the Pacific Plate. Malang Regency is one of the districts included in the level of high hazard classification for tectonic earthquakes that can cause Tsunamis at any time. The purpose of this study is whether the Tsunami disaster simulation can affect the level of community resilience. This research method is quantitative pre-experimental design using a one-shot case study approach. The number of samples used amounted to 58 people using purposive sampling techniques. The instrument used was a community resilience questionnaire that would be tested using the One-sample t-test. The results of this study found that the value of community resilience after a tsunami disaster simulation averaged more than 100, which means that community resilience is good. P-value calculated s alpha value (0.05). The conclusion of this research is the Tsunami disaster simulation method can influence the level of community resilience.
\end{abstract}

Keywords: Simulation, Tsunami, Community resilience, pre-experimental design

Abstrak: Indonesia merupakan Negara dengan potensi risiko tinggi terjadinya berbagai macam jenis bencana, karena Indonesia terletak di antara tiga lempeng tektonik besar bumi, yaitu Lempeng Eurasia, Lempeng Indo-Australia, dan Lempeng Pasifik. Kabupaten malang merupakan salah satu kabupaten yang masuk dalam tingkat klasifikasi bahaya tinggi terhadap bemcana gempa bumi tektonik yang dapat menimbulkan Tsunami sewaktu-waktu. Tujuan dari penelitian ini adalah apakah simulasi bencana Tsunami dapat mempengaruhi tingkat ketangguhan masyarakat. Metode penelitian ini adalah kuantitatif pre experimental design dengan menggunakan pendekatan one shote case study. Jumlah sampel yang digunakan berjumlah 58 orang dengan menggunakan teknik purposive sampling. Instrumen yang digunakan adalah kuesioner ketangguhan masyarakat yang akan diuji menggunakan uji One sample $t$ test. Hasil penelitian ini didapatkan bahwa nila ketangguhan masyarakat setelah dilakukan simulasi bencana Tsunami rata-rata lebih dari 100, yang berarti bahwa ketangguhan masyarakat baik. Nilai $P$ hitung > nilai alpa (0.05). Kesimpulan penelitian ini adalah metode simulasi bencana Tsunami dapat mempengaruhi tingkat ketangguhan masyarakat.

Kata kunci: Simulasi, Tsunami, Ketangguhan Masyarakat, pre eksperimental design

\section{PENDADULUAN}

Indonesia merupakan Negara yang memiliki tingkat kerawanan tinggi terhadap terjadinya bencana yang disebabkan oleh faktor alam. Secara geografis Indonesia berada di jalur pegunungan aktif yang mempertemukan 3 lempeng tektonik besar, yaitu lempeng Eurasia, lempeng IndoAustralia, dan lempeng Pasifik serta terletak di daerah katulistiwa yang menyebabkan terjadinya bencana alam. Lempeng-lempeng tersebut dapat bergerak aktif sewaktu-waktu dan saling bertumbukan antar lempeng. Dampak dari tumbukan lempeng tektonik tersbut menyebabkan terjadinya bencana alam, seperti gunung api, tanah longosr, gempa bumi, dan tsunami. Dari banyaknya potensi terjadinya bencana alam tersebut Indonesia disebut sebagai supermarket dari bencana alam, artinya Indonesia disebut juga Negara dengan potensi bencana terbanyak.
Ada 28 wilayah di Kepulauan Indonesia yang dinyatakan sebagai wilayah rawan bencana. Salah satunya adalah Jawa Timur wilayah selatan khususnya, memiliki tingkat kerentanan yang besar apabila dibandingkan dengan pulau-pulau lainnya, karena berbatasan langsung dengan samudra Hindia. Kabupaten Malang merupakan salah satu kabupaten yang masuk dalam tingkat klasifikasi bahaya Tinggi terhadap bencana gempa bumi tektonik, dan menempati urutan ranking ke 60 tingkat nasional.

Kabupaten Malang masuk dalam jalur pertemuan lempeng Eurasia dengan lempeng Indo-Australia. Pertemuan lempeng itu berada di $200 \mathrm{~km}$ arah selatan. Dengan dilaluinya pertemuan dua lempeng tersebut, maka di wilayah selatan Jawa Timur berpotensi terjadinya gempa bumi tektonik serta tsunami.

Penentuan tingkat potensi bahaya tsunami dapat dilihat dari data-data kegempaan, aspek geomorfologi, aspek 
tektonik, serta berdasarkan metode indeks ancaman bahaya. Pada hasil penelitian yang dilakukan oleh Fadhil (2016) mengatakan bahwa terdapat ancaman bahaya tsunami dengan tingkat tinggi di beberpa pantai dikabupaten malang, salah satunya adalah pantai Ngliyep dengan total luas 135,72 $\mathrm{Ha}$. Sedangkan studi risiko Tsunami di pesisir selatan Kabupaten Malang yang dilakukan oleh Koswara (2015) menyebutkan bahwa tingkat kerentanan dan ancaman tertinggi terletak pada kecamatan Donomulyo, dimana pantai Ngliyep berada.

Untuk menyikpai ancaman bencana tersebut, kesiapsiagan sangatlah penting karena bencana tidak dapat dihindarkan atau dicegah, tetapi bagaimana masyarakat yang berisiko terpapar bencana dapat menyiapkan diri dan keluarga dalam menghadapi ancaman bencana tersebut. Untuk meningkatkan kesiapsiagaan masyarakat dari ancaman bencana tersebut perlu dilakukan pembelajaran atau pelatihan dalam menghadapi bencana. Salah satu metode pembelajaran yang dapat dilakukan oleh masyarakat adalah metode pembelajaran sosial, yaitu metode simulasi.

Simulasi adalah sebuah replikasi atau visualisasi dari perilaku sebuah sistem, misalanya sebuah perencaan penedidikan, yang berjalan pada kurun waktu tertentu. Dapat dikatakan bahwa simulasi adalah sebuah model yang berisi seperangkat variabel yang menampilkan ciri utama dari sistemkehiudpan yang sebenarnya. Simulasi juga dikatakan sebagai metode pembelajaran yang dapat digunakan dalam pembelajaran kelompok (Ikhwan, 2017).

Uno (2007) dalam Syuaib (2013) mengatakan bahwa metode pembelajaran sosial ini menekankan hubungan individu dengan masyarakat atau orang lain. Dalam proses pembelajaran ini peserta didik dipaparkan pada susana manipulatif dalam kondisi bencena, saling berinteraksi satu sama lainnya. Simulasi merupakan cara penyajian pengaaman belajar dengan menggunakan situasi tiruan utnuk memahami tentang konsep, prinsip atau ketrampilan tertentu. Sanjaya (2013) dalam indiasari (2016) mengatakan bahwa simulasi dapat digunakan sebagai metode mengajar dengan asumsitidak semua proses pembelajaran dapat dilakukan secara langsung pada obyek yang sebenarnya.

Hasil survei di Jepang, pada kejadian gempa Great Hanshin Awaji 1995, menunjukkan bahwa presentase korban selamat disebabkan oleh Diri Sendiri sebesar 35\%, Anggota Keluarga 31,9\%, Teman/Tetangga $28,1 \%$, Orang Lewat
2,60\%, Tim SAR 1,70\%, dan Iain-lain 0,90\% (Supartini et al., 2017). Berdasarkan data tersebut, sangat jelas bahwa faktor yang paling menentukan adalah dirinya sendiri. Maka, edukasi untuk meningkatkan pemahaman risiko dengan melibatkan masyarakat di daerah rawan bencana merupakan upaya dalam proses penyadaran (awareness) untuk meningkatan kemampuan dirinya sendiri. Tujuan dari penelitian ini adalah untuk menganalisis pengaruh metode simulasi bencana Tsunami terhadap peningkatan ketangguhan masyarakat pesisir pantai Ngliyep Kabupaten Malang.

\section{METODE PENELITIAN}

Metode penelitian ini menggunakan penelitian kuantitatif pre eksperimental desing dengan menggunakan pendekatan One-shot Chase Study, yaitu sebuah eksperimen yang dilaksanakan tanpa adanya sekelompok pembanding dan juga tanpa tes awal. Dalam penelitian ini tidak ada kelompok kontrol dan sampel penelitian diberikan perlakuan metode simulasi bencana Tsunami, yaitu dengan memberikan stimulus berupa skenario terjadinya bencana Tsunami serta melibatkan masyarakat dan pemangku kepentingan pada situasi bencana Tsunami tersebut. Seblum dilakukan simulasi, masyarakat dan pemangku kepentingan diberikan penjelasan terlebih dahulu peran dari masing-masing. Kemudian setelah dilakukan metode simulasi, sampel diberikan kuesioner ketangguhan masyarakat. Teknik pengumpulan data menggunakan kuesioner ketangguhan masyarakat. Kuesioner ini terdiri dari 51 item pertanyaan yang dibagi menjadi 5 domain, yaitu pengetahuan terhadap risiko bencana, pengkajian risiko bencana, perencanaan kegiatan untuk menurunkan risiko bencana, pelaksanaan kegiatan pengurangan risiko bencana dan sistem komunikasi dan pemerintahan. Kuesioner tersebut menggunakan skala likert 0 sampai 4 , rentang nilai total skor tersebut adalah 0-200, yang mana rentang tersebut terdiri dari ketangguhan masyarakat sangat kurang (0-50), ketangguhan masyarakat kurang (51100), ketangguhan masyarakat baik (101- 
150), dan ketangguhan masyarakat sangat baik (151-200). Data diuji normalitas terlebih dahulu, kemudian dilakukan uji statistik menggunakan One sampel $t$ Test. Sampel yang digunakan adalah masyarakat Desa Rawan Bencana Tsunami yaitu di pesisir Pantai Nyliyep sebanyak 58 Orang, teknik sampling menggunakan purposive sampling.

\section{HASIL PENELITIAN}

Syarat mutlak pada uji t-test adalah data harus berdistribusi normal (Sugiyono, 2015), untuk itu sebelum dilakukan uji t-test data diuji kenormalannya. Pada penelitian ini uji normalitas data menggunakan uji Shapiro Wilk. Hasil uji normalitas data penelitian ini adalah 0.313. Dari hasil tersebut menunjukkan bahwa nilai sig. Shapiro Wilk lebih besar dari pada nilai alpa (0.05), maka dapat disimpulkan bahwa data tersebut berdistribusi normal dan dapat dilanjutkan untuk dilakukan uji t-test. Hasil uji normalitas dapat dilihat pada tabel 2.

Tabel 1. Hasil Uji Normalitas Data

\begin{tabular}{cccccccc}
\hline & \multicolumn{3}{c}{ Kolmogorov-Smirnov(a) } & \multicolumn{4}{c}{ Shapiro-Wilk } \\
\cline { 2 - 7 } & Statistic & df & Sig. & Statistic & df & Sig. \\
\hline Ketangguhan & .090 & 58 & $.200\left(^{*}\right)$ & .976 & 58 & .313 \\
\hline
\end{tabular}

Dari tabel di atas menunjukkan bahwa pada uji Shapiro-Wilk nilai signifikansi $>$ nilai alpa (0.05) yang artinya data tersebut berdistribusi normal. Dengan demikian uji hipotesis menggunakan One Sample $t$ Test dapat dilanjutkan. Hasil uji One sample $t$ Test dapat dilihat pada tabel berikut.

Tabel 2. Hasil Uji One-Sample Test

\begin{tabular}{|c|c|c|c|c|c|c|}
\hline \multirow{3}{*}{ Variabel } & \multicolumn{6}{|c|}{ Test Value $=100$} \\
\hline & \multirow[t]{2}{*}{$t$} & \multirow[t]{2}{*}{$\mathrm{df}$} & \multirow[t]{2}{*}{ Sig. (2-tailed) } & \multirow{2}{*}{$\begin{array}{c}\text { Mean } \\
\text { Difference }\end{array}$} & \multicolumn{2}{|c|}{$\begin{array}{l}\text { 95\% Confidence Interval of the } \\
\text { Difference }\end{array}$} \\
\hline & & & & & Lower & Upper \\
\hline Ketangguhan & 65.074 & 57 & 0.000 & 38.379 & 134.12 & 142.64 \\
\hline
\end{tabular}

\section{PEMBAHASAN}

Hasil penelitian menunjukkan bahwa nilai sig. Lebih kecil dari pada nilai alpa (0.05) maka nilai rata-rata tingkat ketangguhan masyarakat setelah dilakukan simulasi bencana Tsunami lebih dari 100, yang artinya ketangguhan masyarakat baik. Dengan menggunakan metode simulasi dapat mengukur kesiapan seseorang dalam menghadapi bencana. Memberikan pendidikan melalui metode simulasi dapat memberikan hasil yang lebih baik dibandingkan dengan yang tidak menggunakan metode simulasi (Indriasari, 2016).

Hisbuan dan Mudjiono (2008) dalam Ferianto (2019) mengatakan bahwa simulasi adalah tiruan atau perbuatan yang hanya pura-pura. Sedangkan Ikhwan (2017) mengartikan simulasi sebagai cara penyajian pengalam belajar dengan menggunakan situasi tiruan untuk memahami tentang konsep, prinsip, atau ketrerampilan tertentu. Dalam penelitian ini masyarakat di berikan sebuah skenario bencana Tsunami yang melibatkan peran serta masyarakat dan juga stakeholder, sehingga masyarakat akan memahami apa yang akan mereka lakukan ketika bencan itu terjadi. Sebelum dilakukan simulasi dari pihak BPBD Kabupaten Malang memberikan sedikit pengetahuan tentang Tsunami dan juga apa yang harus dilakukan oleh masyarakat tersebut. Hasil dari penelitian ini dapat dilihat rata-rata nilai 
dari ketangguhan masyarakat lebih dari 100 , yang artinya ketangguhan masyarakat tersebut baik.

Kristanto (2016) mengatakan bahwa dengan pemberian model pembelajaran simulasi pada siswa tenatang pertolongan pertama pada kecelakaan hasilnya lebih baik dari pada pembelajaran menggunakan model ceramah. Keunggulan dari metode ini adalah perhatian peserta didik terpusat pada hal-hal yang penting dan langsung dipraktikkan. Penelitian yang dilakukan oleh Kristanto (2016) juga menunjukkan bahwa terdapat perbedaan yang signifikan antara kelompok dengan menggunakan metode ceramah dengan kelompok simulasi. Metode simulasi akan melihat pembelajaran secara langsung pada objek yang sebenarnya. Masyarakat akan mempraktikkan siapa dan berbuat apa, sehingga masyarakat akan mempelajari peran mereka masing-masing. Dengan metode ini masyarakat tidak hanya mendapatkan pengetahuan tentang penanggulangan bencana Stunami, tetapi juga meningkatkan sikap dan keterampilan mereka.

Dengan menggunakan metode simulasi masyarakat disajikan sebuah pengalaman belajar dengan menggunakan situasi tiruan berupa bencana Tsunami untuk memahami tentang konsep, prinsip serta tindakan yang dilakukan ketika terjadi bencana Tsunami. Syuaib (2013) mengatakan bahwa metode pembelajar mempengaruhi kesiapsiagaan dalam menghadapi bencana. Pada metode simulasi terdapat kelebihan dan kelemahan, diantaranya adalah simulasi dapat dujadikan sebagai bekal bagi para masyarakat dalam mendapatkan pengetahuan tentang bencana alam yang sesuai dengan situasi sebenarnya, metode simulasi juga dapat mengembangkan kreativitas masyarakat dalam menghadapi suatu bencana alam, karena melalui simulasi ini masyarakat diberikan kesempatan untuk melakukan perannya sesuai dengaan kenyataan dimasyarakat.

Metode simulasi dalam peningkatan ketangguhan masyarakat dilatih dalam hal koordinasi, komunikasi dan evakuasi dengan melibatkan seluruh pemangku kepentingan (pemerintah dan masyarakat umum). Seluruh pihak yang terlibat baik masyarakat umum maupun pemerintah mensimulasikan situasi bencana sesungguhnya menggunakan skenario bencana yang dibuat mendekati atau sesuai dengan kondisi nyata pada saat bencana. Dengan melibatkan peran aktif masyarakat, maka ketangguhan masyarakat akan meningkat (Indriasari, 2016).

Berdasarkan data yang diperoleh bahwa setelah dilakukan simulasi bencana Tsunami sebagian besar responden dalam hal ini adalah masyarakat mempunyai tingkat ketangguhan yang tinggi. Hal ini sesuai dengan hasil penelitian yang dilakukan oleh Ferianto \& Hidayati (2019) yang mengatakan bahwa metode simulasi efektif dalam peningkatan perilaku kesiapsiagaan siswa. Dengan menggunakan metode simulasi memberikan dampak positif bagi masyarakat dalam menghadapi bencana Tsunami. Metode simulasi juga dapat meningkatkan ketangguhan masyarakat karena masyarakat berinteraksi dengan lingkungan di sekitar mereka.

Olson et,al (2010) dalam ferianto (2019) mengatakan bahwa pendidikan tentang siaga bencana dengan menggunakan simulasi berupa game atau permainan dapat memberikan hasil yang lebih baik dibandingkan dengan yang tidak menggunakan metode simulasi. Menggunakan metode simulasi dengan role play dapat membantu mengendalikan aktivitas yang berlebihan, melatih kemampuan mempertahankan perhatian pada objek tertentu, dan mengendalikan tingkat angresivitas. Hal ini dapat dibuktikan dengan hasil penelitian ini, yaitu tingginya nilai ketangguhan masyarakat setelah dilakukan metode simulasi tentang bencana Tsunami. Masyarakat akan terfokus terhadap objek yang telah diberikan tentang bagaimana penanggulangan ketika bencana Tsunami terjadi, sehingga masyarakat akan belajar bagaimana cara menanggulangi bencana Tsunami.

Hasil penelitian ini menunjukkan bahwa nilai ketangguhan masyarakat tinggi. Dengan menggunakan metode simulasi masyarakat akan saling berinteraksi satu sama lain. Aktivitas masyarakat cukup tinggi sehingga terlibat langsung dalam pembelajaran penaggulangan bencana Stunami. Dalam simulasi ini masyarakat dapat memahami bagaimana menghadapi jika bencana Stunami terjadi. Pada penelitian ini simulasi yang digunakan 
adalah simulasi bencana Tsunami yang diadakan oleh BPBD (Badan Penanggulangan Bencana Daerah)

\section{KESIMPULAN DAN SARAN}

Kesimpulan dari penelitian ini adalah nilai rata-rata ketangguhan masyarakat setelah dilakukan simulasi bencana Tsunami lebih dari 100. Hal ini dapat diartikan bahwa simulasi bencana Tsunami dapat mempengaruhi tingkat ketangguhan masyarakat. Sehingga metode ini dapat

\section{DAFTAR PUSTAKA}

Anggraini, Y., Domai, T., \& Said, A. (2015). Implementasi Program Pengembangan Desa Pesisir Tangguh (PDPT) dalam Upaya Pembangunan Wilayah Pesisir. Jurnal Administrasi Publik, 18621867.

BNPB. (2018). Dibi BNPB. Diambil kembali dari Badan Nasioanl Penanggulangan Bencana: http://dibi.bnpb.go.id/dibi/

Damanik, H. B., \& Susanti, S. S. (2017). Kesiapsiagaan Bencana Tsunami pada Tuna Netra. Jurnal IImiah Mahasiswa Universitas Syiah Kuala, 1-10.

Debora, O., Wahyudi, Y., Fatmawati, D. N., Susantyo, A., Sulityono, Sardjono, . . . Mumpuni, R. Y. (2018). Panduan Teknis Pengabdian Masyarakat Panduan Kegiatan Peningkatan Ketangguhan Masyarakat Oleh Mahasiswa dan Dosen-AIPTINAKES JATIM. Malang: Alta Pustaka.

Demonda, N. I., \& Pamungkas, A. (2014). Penentuan Zona Kerentanan Bencana Gempa Bumi Tektonik di Kabupaten Malang Wilayah Selatan. Jurnal Teknik Pomits, 2301-9271.

Fadhil, M., Purwanto, H. S., \& Nugroho, A. R. B. (2016). Geologi dan kajian risiko bencana tsunami daerah bajulmati dan sekitarnya kecamatan gedangan, kabupaten malang.

Fallen, R., \& Dwi, R. B. (2011). Catatan Kuliah: Keperawatan Komunitas. Yogyakarta: Nuha Medika.
Kabupaten Malang. Keterlibatan semua unsur masyarakat.

digunakan untuk meningkatkan ketangguhan masyarakat di Daerah rawan bencana lainnya. Saran untuk peneliti selanjutnya adalah supaya melakukan penelitian dengan jumlah sampel yang lebih besar dan menggunakan metode penelitian true eksperimental dan menggunakan kelompok kontrol untuk mengurangi bias.

Farhi, Z., Sudibyakto, \& Hadmoko, D. S. (2012). Tingkat Kerentanan dan Indeks Kesiapsiagaan Masyarakat Terhadap Bencana Tanah Longsor Di Kecamatan Bantarkawung Kabupaten Brebes. Majalah Geografi Indonesia, 80-97.

Ferianto, K., \& Hidayati, U. N. (2019). Simulasi Terhadap Perilaku Kesiapsiagaan Bencana Banjir Pada Siswa Sman 2 Tuban. Mesencephalon Jurnal Kesehatan STIKes Kepanjen, 5(2), 88-94.

Hella, P. M., Haryono, B. S., \& Siswidiyanto. (2015). Perencanaan Skenario Kesiapsiagaan Terhadap Bencana Alam Di Wilayah Pesisi Kabupaten Malang. Jurnal Administrasi Publik, 1924-1929.

Ikhwan, A. (2017). Metode Simulasi Pembelajaran dalam Perspektif Islam. Jurnal Pendidikan Islam, 2(2), 1-34.

Indriasari, F. N. (2016). PENGARUH PEMBERIAN METODE SIMULASI SIAGA BENCANA GEMPA BUMI TERHADAP KESIAPSIAGAAN ANAK DI YOGYAKARTA. Jurnal Keperawatan Soedirman, 11(3), 17.

Koswaraa, A. Y., Wahyudi, \& Sambodho, K. (2015). Studi Risiko Tsunami Di Wilayah Pesisir Selatan Kabupaten Malang. Prosiding Seminar Nasional Manajemen Teknologi XXIII (hal. A29-1). Surabaya: Program Studi MMT-ITS. 
Maarif, S. (2013). Initiation of the Desa Tangguh Bencana Through Stimulus-Response Method. Indonesian Journal of Geography, 44(2).

https://doi.org/10.22146/indo.j.geog, 2399

Maulana, E., \& Wulan, T. R. (2015). Pemetaan Multi-Rawan Kabupaten Malang Bagian Selatan Dengan Menggunakan Pendekatan bentangalam. Simposium Nasional Sains Geoinformasi 2015 (hal. 526534). Yogyakarta: Puspics Fakultas Geografi Universitas Gadjah Mada.

Muis, I., \& Anwar, K. (2018). Model Kesiapsiagaan Masyrakat dalam Pengurangan Risiko Bencana Tanah Longsor di Desa Tugumukti, Kecamatan Cisarua Kabupaten Bandung Barat. Asian Social Work Journal, 19-30.

Naryanto, H. S. (2003). Migitasi Kawasan Pantai Selatan Kota Bandar Lampung, Propinsi Lampung terhadap Bencana Tsunami. Alami.

Naryanto, H. S., \& Wisyanto. (2005). Kajian dan Analisis Potensi Bencana Tsunami Konfigurasi Pantai Serta Mitigasi Bencana Di Pantai Selatan Jawa Timur: Belajar dari Pengalaman Bencana Tsunami Banyuwangi Tahun 1994. Alami.

Paramesti, C. A. (2011). Kesiapsiagaan Masyarakat Kawasan Teluk Pelabuhan Ratu Terhadap Bencana Gempa Bumi dan Tsunami. Jurnal Perencanaan Wilayah dan Kota, 113-128.

PERKA. (2012). Peraturan Kepala Badan Nasional Penanggulangan Bencana Nomor 1 Tahun 2012: Pedoman penyusunan rencana penanggulangan bencana. Jakarta: Badan Nasional Penanggulangan Bencana

Ramadhani, P. (2012). Ketangguhan Masyarakat Di Daerah Rawan Banjir (Studi Kasus pada Masyarakat di RW 10 Kelurahan Bukit Duri, Jakarta Sealatan). FISIP UI, 1-16.
Sastroasmoro, S., \& Ismael, S. (2012). Dasar-dasar Metodologi Penelitian Klinis. Jakarta: CV. Sagung Seto.

Sholihah, T. A., \& Maryanto, A. (2018). Pengaruh Penggunaan Subject Specific Pedagogy (SSP) IPA Berbasis Model Pembelajaran Inkuiri Terhadap Peningkatan Kesiapsiagaan Bencana Tsunami dan Pemahaman Konsep Siswa SMP. Jurnal Pendidikan IPA, 399405.

Sugiyono. (2004). Metode Penelitian Administrasi. Bandung: Alfabeta.

Sugiyono, P. D. (2015). Metode Penelitian \& Pengembangan Research and Development. Bandung: Alfabeta.

Stommel M and Wills C. 2004. Clinical Research : Concepts and Principles for Advanced Practice Nurses. United States of America : Lippincott Williams \& Wilkins

Supartini, E., Kumalasari, N., Andry, D., Susilastuti, Fitrianasari, I., Tarigan, J., ... Nugi, R. (2017). Buku Pedoman Latihan Kesiapsiagaan Bencana: Membangun Kesadaran, Kewaspadaan dan Kesiapsiagaan Dalam Menghadapi Bencana. Badan Nasional Penanggulangan Bencana.

Syuaib, M,Z (2013) Pengaruh Strategi Pembelajaran Simulasi Vs Bermain Peran dan Sikap Siswa terhadap Pengetahuan dan Kesiapsiagaan tentang Bencana Alam. Jurnal Pendidikan Humaniora. 177-189

Undang-Undang. No. 24.2007. Penanggulangan Bencana. UU RI

Utaminingsih, A., Hakim, M. L., \& Azis, A. A. (2014). Implementasi Kebijakan Penanggulangan Bencana Di Daerah (Studi Kebijakan Penanggulanagan Bencana Di Kabupaten Malang). Prosiding Seminar Nasional Bisnis dan Manajemen (hal. 16-27). Malang: Politeknik Negri Malang. 